\title{
OBITUARY
}

\section{Charles Stewart}

Dr. Charles C. Stewart, one of Canada's most senior anaesthetists, died in Montreal on January 19, 1958, aged 70.

Dr. Stewart was born in Scotland, came to Canada as a young man, and commenced the study of medicine at McGill in 1912. Like many other rredical students of that era, he enlisted in 1915 in the ranks of No. 3 McGill General Hospital, and soon was sent to France. He was promoted to the rank of Corporal, was instructed how to "pour ether," and he soon was spending his full time as an anaesthetist. In 1918 he returned to McGill, graduated in 1921; and after internship at the Montreal General Hospifal he started the practice of anaesthesia. In 1928 he succeeded the late Dr. Heppurn as anaesthetist-in-chief at the Montreal General Hospital and continued in that post until his retirement in 1954 After this he served at the Reddy Memorial Hospital, Montreal, but was incapacitated by a stroke early last summer.

Dr. Stewart was an enthusiastic clmical teacher, and long before there was any organized university teaching of anaesthesia he trained many anaesthetists on an apprenticeship basis. These doctors now recall Dr. Stewart's guidance and friendship with great appreciation.

When the Department, of Anaesthesia was organized at McGill in 1946, Dr. Stewart was named an Assistant Professor, and he took an active part in the teaching programme untıl he retired from the Montreal General Hospital. He was an original member of the Anesthetists' Travel Club, organized by Dr. John Lundy and Dr. Ralph Waters in 1929, now reorganized as the Academy of Anesthesiology. He received the Diploma in Anaesthetics of the Royal College of Surgeons of England, was certified in anaesthesia by the Royal College of Physicians and Surgeons of Canada, and by the College of Physicians and Surgeons of Quebec. He was a member of the Canadian Anaesthetists' Society from the time of its founding in 1943.

Dr. Stewart is survived by his wife, the former Lillian Adair of Montreal, and by two sons and one daughter. We extend to Mrs. Stewart, and the members of her family, the heartfelt sympathy of all Canadian anaesthetists. 